\title{
THE NATIONAL PARKS COMMISSION
}

$\mathrm{T}$ HE fifteenth annual report of the National Parks Commission* covers the year ending September 30, 1964 , and, like the present report of the Nature Conservancy, it makes special reference to the study conference, "The Countryside in 1970", held in November 1963. It also comments on the acute problem presented by coastal preservation and development and, like the Conservancy, welcomes the action of the National Trust in initiating 'Enterprise Neptune', the object of which is the conservation of selected stretches of coast line in co-operation with local planning authorities. On water supply problems the Commission regards with grave misgiving any scheme which would begin to abstract water from Ullswater, and adds that any proposals to flood the Winster Valley would be resisted most strongly. During the year under review new orders designating the forest of Bowland and Chichester harbour as areas of outstanding natural beauty were confirmed, but decisions are awaited regarding the Chilterns and the Solway coast areas. The Pennine Way long-distance footpath has now been completed, and provides a strenuous high-level walk from Edale, in the Peak District National Park, to the Cheviots and the Scottish border, passing through two other National Parks, the Yorkshire Dales and Northumberland. Special efforts have been made to assist local authorities in resolving difficulties, and in negotiating outstanding footpath agreements, in their areas regarding the Offa's Dyke path, but coastal erosion still presents difficulties in maintaining the south-west peninsular coast footpath. The definitive maps for the south Devon coastal area are now complete and should simplify consideration of outstanding public rights of way on the Devon south coast path, while some progress is reported with regard to the South Downs way.

The report includes brief accounts of progress during the year with each of the 10 national parks, but development questions continue to present the Commission with its main problems, and some 410 proposals for development affecting landscape beauty in national parks were referred to the Commission during the year. The Commission notes that the South Wales Electricity Board

* National Parks and Access to the Countryside Act, 1949. Fifteenth Report of the National Parks Commission for the year ended September 30 , 1964. Pp. vii $+89+8$ plates. (London: H.M.S.O., 1964.) 8 s. net. proposed to carry out, during the year 1964-65, the first stages of an operation involving the expenditure of $£ 50,000$, primarily to improve visual amenities in the electricity distribution network area of South Wales. Strenuous efforts have boen made by the two Yorkshire National Parks planning authorities, with the support of the Commission, to effect a change in the policy of the North East Electricity Board with regard to overhead supply lines. With regard to the $4,000-\mathrm{kV}$ line in the southern counties, for which the Commission suggested alternative routes, the Commission has asked that, should the Minister of Power decide that the case for consent to the Electricity Board's proposed route is overwhelming, a definite time limit should be set for the removal of the lines, the towers and the bases, and that the period should be as short as possible. The Commission has also discussed with the Central Electricity Generating Board the project for a pump storage scheme in North Devon, with regard to the possible effects on the coast, including the approaches from land and sea and the recreational potential which the upper reservoir or reservoirs may have. The Minister of Power has again been approached with regard to the placing underground of the electricity lines in Martindale in the Lake District National Park.

Representations were made to the Minister of Transport regarding the proposal to withdraw passenger services from the Taunton to Barnstaple line, but without effect. The Minister of Transport, however, has decided to continue passenger services on the line from Llandudno junction to Blaenau Ffestiniog line, closure of which was also opposed by the Board. The Commission particularly welcomes the Minister of Transport's statement to the Ramblers Association regarding traffic restrictions in the remote countryside, particularly his view that he would expect the Highway Authorities to take into account the views of the National Park Planning Authorities in sub. mitting improvement schemes to him for grant purposes. The Minister also said that he was ready to consider orders made on grounds of amenity so long as provision was made for carrying on the normal life of the district without imposing unreasonable burdens. Further reference to this question and also to the Commission's present views regarding recreational facilities in National Parks is made on p. 632 of this issue of Nature.

\section{NUFFIELD FOUNDATION SCIENCE TEACHING PROJECT: PROGRESS REPORT}

\begin{abstract}
$\mathrm{T}$ HE progress report of the Nuffield Foundation Science Teaching Project* appeared towards the end of 1964 . The work is now being extended to cover the teaching of science to children of all ages in most types of schools. Work began in 1961 on the design of courses leading to O-level examinations in physics, chemistry and biology. Programmes for the improvement of science and mathematics teaching have already been announced. The progress report now published describes some of the plans being made to design science courses for sixth forms and for 'Newsom' children (the less able half of the school population) in the 13-16 year range.

Since the preparation of the report, the Nuffield Trustees have allocated a further $£ 115,000$ to science teaching, chiefly to support A-level biology. So far

* The Nuffeld Foundation Science Teaching Project. Progress Report, October, 1964. Pp. 31. (London: Longmans, Green and Co., Ltd., and
Penguin Books. Published for the Nuffield Foundation.)
\end{abstract}

$£ 550,000$ has been set aside for science teaching, but this figure does not cover work in the physical sciences in the sixth form and the proposed programme for the 'Newsom' children. During the next year a sum of a quarter of a million pounds will have to be spent on the first printing of the teachers' guides and pupils' books due to be published in April 1966.

A hundred and fifty British secondary schools and a total of three thousand children in more than two hundred classrooms are being used in the controlled testing of the O-level courses. This is most necessary: far too many text-books are the results of their authors' attempts to dilute or re-present material from the standard works. Large groups of children will have to be the yard-sticks by which teaching material is validated. This absorbs time and money and may prove to be inhibiting to the over-facile writer of school text-books, but it is the only permissible way for the future. 
Another guiding principle is that science should be made intelligible and enjoyable, even in the work of the public examinations. Experimental work is a conspicuous part of the Nuffield courses. Many local authorities have helped to give the courses a fair trial by spending soveral hundreds of pounds a school on new scientific equipment.

Alternative O-levol examinations for children using Nuffield courses in physics, chemistry and biology are to be provided by the public examinations in the years ahead, so that children engaged in the testing of new courses will not be hampered. A hundred titles in the first printing of about three million books will appear in spring
1966 and, in addition, there are films, film loops and other special itoms of equipment developed during the programme, and other visual aids.

The future of the $\mathrm{O}$-level courses is said in the report to depend on tho extent to which practising teachers will be helped to make the best use of the new methods. No charitable organization can be responsible for the work in the future, and the Department of Education and the local education authorities will have to give major support. The report outlines future developments, including a project to teach general science in the 11-13 age range.

W. L. SUMNER

\section{ANTIMICROBIAL AGENTS AND CHEMOTHERAPY}

$\mathrm{V}$ ARIOUS aspects of antimicrobial agents, infectious diseases, microbiology, and chemotherapy were discussed in the 162 papers presented at the fourth Interscience Conference on Antimicrobial Agents and Chemotherapy. This meeting was held in New York during October 26-28, 1964, under tho sponsorship of the American Society for Microbiology and organized with the co-oporation of the Infectious Diseases Society of America. Dr. N. Bohonos (Lederle Laboratories) was chairman of the conference. 1,045 scientists attended this meeting, including representatives from eighteen countries in all.

The three-day conference opened with an address by Dr. M. Finland (retiring president of the Infectious Diseuses Society) on problems in the clinical investigation of new drugs. The role of the U.S. Food and Drug Administration and other rogulatory agencies was reviewed, and the necessity of allowing the investigator to exercise some initiative and responsibility was mentioned. The John Scott Award for meritorious seientific achievement was presented at this session by the City of Philadelphia (Pennsylvania) to Prof. J. C. Sheehan (Massachusetts Institute of 'Technology) for his research loading to tho preparation of the 'semi-synthetic penicillins'.

Among the features of the 1964 meeting wore four symposia. Prof. M. Hamburger chaired the first, which dealt with "Penicillins and Cephalosporins" and included reviews of the clinical status of cephalothin (by W. M. M. Kirby), ampicillin (by S. Ross), oxacillin and methicillin (by H. Simon), and nafcillin (by C. M. Martin). P. B. Bunn described his experience with penicillin allergy and emphasized the apparent lack of strong sensitivity to ampicillin of patients allergic to benzylpenicillin (penicillin $G)$. It was obvious that some of these newor semi-synthetic penicillins were as clinically useful in treatment of certain Gram-negative infections as some of the other antibiotics, for example, chloramphenicol, polymyxin, and colistin. However, as Prof. Simon pointed out, we do not as yet have a 'panaceamycin' for all infections. M. R. Pollock, (National Institute for Medical Research, London) summarized his investigations of the $\beta$-lactamasos of bacteria. These enzymes, which inactivate both penicillins and cephalosporins under laboratory conditions, may not be entirely responsible for the penicillin resistance noted in certain bacterial cultures.

Dr. H. C. Reilly (Sloan Kettering Institute) presided over a symposium on "Antinooplastic Antibiotics". S. A. Schepartz reviewed the programme of the Cancer Chemotherapy National Screening Center, in which searches are being made for anti-neoplastic antibiotics from fermentation processes. Thirty materials (isolated from more than 115,000 'crude' broths screened) have been considered for clinical evaluation, but none has shown 'great promiso'. An investigation of the incidence of anti-neoplastic activity among antibiotics that act as inducers of lysogenio bacteria was discussed by $\mathrm{K}$. F. Price (Bristol Laboratories), who found a high correlation between anti-neoplastic activity and induction of lambda phage in $E$. coli W1709. J. J. Fox (Sloan Kettering Institute) reported that gougerotin contains sarcosyl-D-serine in acyl-amino linkage to 4-amino-4-deoxy-hexuronic acid amide, and concluded that the structure proposed earlier for this antibiotic was in error. He pointed out that all known pyrimidine nucleoside antibiotics (elaborated by Streptomyces species) contain cytosine and 4-amino-hexose moieties. A. Bloch and C. A. Nichol (Roswell Park Memorial Institute) commented on the nucleoside antibiotics related to adenosine with special reference to their effects on adenosine phosphorylase, deaminase, and kinase. R. D. Sullivan (Lahey Clinic Foundation, Boston) pointed out that doses $2-2.5$ times as great as those tolerated by single daily injection were woll tolerated by prolonged intravenous infusion of actinomycin $D$, streptonigrin, and mitomycin $C$, and went on to review recent progress in the use of these antibiotics in cancer chomotherapy.

"The Future of Antiviral Drugs" was the subject of a session convened by E. C. Herrmann, jun. (The Mayo Clinic). F. M. Schabel (Southern Research Institute) and I. S. Johnson (Eli Lilly and Co.) discussed the theoretical basis for examining antiviral chemotherapy and problems in the detection of antiviral antibiotics. The successes in viral troatment following the use of 5 -iodo- $2^{\prime}$-deoxyuridine, cytosine, and 5 -azaorotic acid were reviewed by P.Calabresi (Yale University); and R. L. Thompson (National Institutes of Health, Bethesda) summarized the tests with $N$ methylisatin- $\beta$-thiosemicarbazone and other thiosemicarbazones. The promising laboratory and clinical results with l-adamantanamine hydrochloride were reviewed by C. E. Hoffman (E. I. DuPont de Nemours and Co.).

"The Usefulness of Synthetic Antimicrobials" was the subject of a symposium chaired by Dr. D. Lehr (New York Medical College). Dr. J. Alban (Stanford University), E. H. Kass (Harvard University), J. P. Colmore (Oklahoma Medical Center), and D. F. MeDonald (University of Rochester) gave information on the present status of the sulphonamides, nitrofurantoins, and nalidixic acid.

Among the new antibiotics mentioned at the Conference were:

(l) The S-ethyl homologue of lincomycin and $N$ demethyl analogue of lincomycin formed by adding DL-ethionine and $\alpha$-methylthiolincosamide, respectively, to lincomycin-producing fermentations according to Argoudelis et al. (The Upjohn Co.). (2) Everninomicin, a new antibiotic complex derived from Micromonospora carbonacea which inhibits Gram-positive bacteria and PPLO, as shown by Weinstein et al. (Schering Corporation). (3) Almarcetin, a new polypeptide antibiotic which may be useful against phytopathogens, according to Bachler et al. (Northern Regional Research Laboratory, U.S. Department of Agriculture). (4) Monicamycin, an acidic heptaene antifungal agent isolated by Gupta (Regional Research Laboratory, Jammu-Tawi, India). (5) Rubiflavin, a toxic anti-tumour antibiotic described by Aszalos et al. (Squibb Institute for Medical Research). (6) $U-13714$, a 